\title{
Male External Catheter in Adults: a glance at nursing care practice
}

\author{
Cateter Urinário Externo Masculino: um olhar sobre a prática assistencial da Enfermagem \\ Cateter Urinario Externo Masculino: una mirada sobre la práctica asistencial de la Enfermería
}

Vivian Sauer Torres da Silva'

ORCID: 0000-0001-7518-1166

\begin{abstract}
Maria Virginia de Almeida Couto Rosa Torres'
ORCID: 0000-0002-4307-6721

Melina Araújo de Oliveira Silva'

ORCID: 0000-0002-1611-9730

Oneida Silveira Freitas'

ORCID: 0000-0002-2556-7797

Priscila Damaceno Santos'

ORCID: 0000-0002-7628-325X

João Júnior Gomes'

ORCID: 0000-0003-4171-2752

Gisela Maria Assis"

ORCID: 0000-0001-6343-8075
\end{abstract}

'Faculdade de Medicina de São José do Rio Preto.

São José do Rio Preto -SP, Brasil.

"Universidade Federal do Paraná. Curitiba-PR, Brasil.

How to cite this article:

Silva VST, Torres MVACR, Silva MAO, Freitas OS,

Santos PD, Gomes JJ, et al. Male external catheter

in adults: a glance at nursing care practice.

Rev Bras Enferm [Internet]. 2019;72(2):450-4.

doi: http://dx.doi.org/10.1590/0034-7167-2018-0327

Corresponding Author:

Vivian Sauer Torres da Silva

E-mail: viviansts@hotmail.com

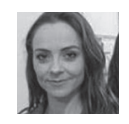

\section{ABSTRACT}

Objective: to describe the patients care in the use of the Male External Catheter in Adults in a clinical-surgical hospitalization unit. Method: a cross-sectional study. Evaluation of 30 patients hospitalized in clinical-surgical units to collect items related to the specific care provided. Results: $100 \%$ had no reference to the use of external catheter in the evolution of the nurse; $43.3 \%$ of the assistants or technicians recorded; $36.6 \%$ presented skin lesions; $100 \%$ had a latex device attached with adhesive tape; $90 \%$ were not submitted to hair removal; $96.7 \%$ had daily genital hygiene; $70 \%$ received no guidance at all. Conclusion: no individualized evaluation was observed for the use of the device, nursing records did not include prescription and description of installation and care, latex device and micropore paper adhesive tape were predominant; skin lesions were prevalent, hygiene and exchange were adequate, few patients were advised regarding the use of the device.

Descriptors: Nursing Care; Nursing Process; Catheters; Urinary Incontinence; Nursing Records.

\section{RESUMO}

Objetivo: descrever a assistência aos pacientes em uso do Cateter Urinário Externo Masculino em unidade de internação clínico-cirúrgica. Método: estudo transversal. Avaliação de 30 pacientes internados em unidades clínico-cirúrgicas para levantamento de itens relacionados ao cuidado específico prestado. Resultados: $100 \%$ não teve referência do uso de cateter externo na evolução do enfermeiro; $43,3 \%$ dos auxiliares ou técnicos realizaram anotação; $36,6 \%$ apresentaram lesão de pele; $100 \%$ estava com dispositivo de látex fixado com fita adesiva; $90 \%$ não foram submetidos à remoção dos pelos; $96,7 \%$ tiveram higiene genital diariamente; $70 \%$ não receberam nenhum tipo de orientação. Conclusão: não se observou avaliação individualizada para uso do dispositivo, os registros de enfermagem não contemplaram prescrição e descrição de instalação e cuidados, dispositivo de látex e fita adesiva microporosa foram predominantes; lesões de pele foram prevalentes, higiene e troca foram adequadas, poucos pacientes foram orientados quanto ao uso do dispositivo.

Descritores: Cuidados de Enfermagem; Processo de Enfermagem; Cateteres; Incontinência Urinária; Registros de Enfermagem.

\section{RESUMEN}

Objetivo: describir la asistencia a los pacientes en uso del Cateter Urinario Externo Masculino en una unidad de internación clínico-quirúrgica. Método: estudio transversal. Evaluación de 30 pacientes internados en unidades clínico-quirúrgicas para el levantamiento de ítems relacionados al cuidado específico prestado. Resultados: el $100 \%$ no tuvo referencia del uso de catéter externo en la evolución del enfermero; el $43,3 \%$ de los auxiliares o técnicos realizaron anotaciones; el 36,6\% presentó lesión de la piel; el $100 \%$ estaba con dispositivo de látex fijado con cinta adhesiva; el $90 \%$ no fue sometido a la remoción de los pelos; el 96,7\% realizó higiene genital diariamente; el $70 \%$ no recibió ningún tipo de orientación. Conclusión: no se observó una evaluación individualizada para el uso del dispositivo, los registros de Enfermería no contemplaron prescripción y descripción de instalación y cuidados; el dispositivo de látex y la cinta adhesiva microporosa fueron predominantes; las lesiones de la piel fueron prevalentes, la higiene y el cambio fueron adecuados, y pocos pacientes fueron orientados en cuanto al uso del dispositivo.

Descriptores: Atención de Enfermería; Proceso de Enfermería; Catéteres; Incontinencia Urinaria; Registros de Enfermería 


\section{INTRODUCTION}

Male External Catheter in Adults (MECA) is a device composed of polyvinyl chloride, latex, polyurethane or silicone that, when placed externally to the penis, facilitates the drainage of urine into a collection flask, replacing diapers and absorbents, and allowing flow control urinary ${ }^{(1)}$. As presented by the Guideline of the European Association of Urology Nursing (EAUN), the MECA is not truly a catheter because it is not inserted through the urethra and instead placed on the penis ${ }^{(1)}$.

It is indicated in men with urgency Urinary Incontinence (UI) and detrusor overactivity without post-void residue ${ }^{(2)}$, in patients with diuresis control in which catheterization is contraindicated (3), and for patients with impaired cognition and/or mobility for spontaneous urination ${ }^{(4)}$. MECA represents a beneficial alternative for men with UI who cannot benefit from curative treatment or during the rehabilitation period ${ }^{(1)}$.

Regarding the relative contraindications, we highlight the problems related to skin integrity or cognitive-behavioral alterations that make it difficult to maintain the $\mathrm{MECA}^{(5)}$. In chronic urinary retention due to detrusor hypoactivity or in retention with high urinary pressure, MECA is absolutely contraindicated if it is thought as a single strategy to control urinary dysfunction, in these cases, urethral catheterization is the option to choose because of the risk of involvement of the renal function ${ }^{(6-7)}$.

The strategy of urine containment by MECA can be used in the short and long term, and its proper function depends on the attachment to the skin, using adhesive tapes or self-adhesive devices after trimming the hairs in order to avoid leaks and skin irritations and ensuring patient comfort ${ }^{(1)}$. The exchange of the device should occur with daily hygiene, except in situations of leakage of the urine or detachment of the device that will imply in more frequent exchanges ${ }^{(1)}$.

The choice of MECA type plays an important role in the prevention of patient complications and comfort. For patients with a known allergy to latex, silicone may be an option as well as a patient with some skin change that does not contraindicate the use of the device but requires greater attention and vigilance because of its transparency. Patients in prolonged use may prefer auto-adhesive options or use of hydrocolloid for fixation, since they are easier to handle and will not use the adhesive tapes that can marry lesions in long term ${ }^{(1)}$.

Despite the high frequency of use of external catheters in care practice, and their potential risk of local complications, there is little discussion about specific care. There are no consistent published studies. Despite the high frequency of use of external catheters in care practice, and their potential risk of local complications, there is little discussion about specific care. There are no consistent published studies ${ }^{(8)}$.

With the publication of the results, it is expected to contribute to the construction of care manuals and protocols that are guided by gaps observed in care, and that lead to specific care in the use of MECA that are assertive and safe.

\section{OBJECTIVE}

This study aims to describe the care provided for patients using MECA, in a clinical-surgical hospitalization unit.

\section{METHOD}

\section{Ethical aspects}

The study was approved by the Committee of Ethics in Research with Human Beings of the Faculdade de Medicina de São José do Rio Preto (FAMERP), on July 13, 2017, and followed all the ethical precepts established by Resolution 466/2012.

\section{Design, place of study and period}

This is a cross-sectional, descriptive exploratory study with a quantitative approach, developed in a university hospital of medium size in a city in São Paulo State countryside. In the hospital complex, four clinical and surgical hospitalization areas were selected: Wards A, B, C and infectious diseases. Data collection occurred between August and December 2017.

The risk involved in the study would be that of embarrassment by the assessment of the genital region, minimized by empathic care and clear explanation. The benefits of the study are in the reflection about the Nursing action in the care for this clientele and direction for the elaboration of care protocols.

\section{Sample and inclusion criteria}

The sample consisted of 30 male patients, constituting all the patients that met the eligibility criteria. Inclusion criteria were: to be over 18 years of age, to be hospitalized in one of the study sites during the period of data collection, to be in use by MECA.

\section{Study protocol}

Data collection was performed by one of the authors of the research, a nurse contracted at the study site. The procedure consisted of a single local assessment and medical record reading, guided by an instrument developed for this purpose, of all patients who met eligibility criteria and accepted to participate in the study.

Initially, the patients' evaluation was carried out and then a review of medical records guided by the data collection instrument in a checklist format, developed by the authors based on EAUN's Guideline of MECA, containing questions regarding: device, hair removal prior to placement, catheter composition material, material used for fixation, skin integrity, urine leakage with MECA, switching frequency, penis hygiene, patient orientation regarding procedure and records in the medical record as annotation, evolution and prescription of nursing.

In addition to the local evaluation of the application of MECA, the researcher talked with the patients about the research, to identify cognitive pattern, as well as the ability to move to reach the urinary reservoir for spontaneous urination or dislocation to the bathroom. The caregivers contributed with this information, describing the behavior and movement of the patients in the period in which they were followed up by them.

\section{Analysis of results and statistics}

The data were organized in an Excel spreadsheet and analyzed with the IBM SPSS Statistics v.20.0 software. Armonk, NY: 
IBM Corp. The results of age were described by mean, Standard Deviation, median and amplitude. For the categorical variables, frequencies and percentages were presented.

\section{RESULTS}

The mean age of the studied sample was 54.8 years (22-82). Table 1 shows the psychomotor condition of the patient using MECA. It was observed that $53.4 \%$ (16) of the patients had preserved cognitive and/or mobility conditions to request micturition aid, demonstrating the inadequate indication of the device.

No patient in the sample had a prescription for MECA care. Table 2 shows that more than half of the patients in use of MECA did not have the indication of the device described in the annotation of nursing by mid-level professionals and no patient had this record in the evolution of the nurse.

Table 3 shows the cutaneous changes observed in the local evaluation and represented by 36.6 (11) of the patients using the MECA.

$100 \%$ of the patients were with latex device. Regarding the fixation of the MECA, in $90 \%$ (27) of the cases the previous hair removal was not performed. Catheter fixation was performed with micropore paper adhesive tape in $83.3 \%$ (25) of the cases, $10 \%$ (3) showed leakage of urine by inadequate fixation of the catheter.

Regarding the specific care provided to patients with MECA, Table 4 shows that 70\% (21) were not advised on the need for catheter use. The frequency of replacement of the catheter was normally daily, associated to the moment of the bath.

Table 1 - Indication of the device, according to cognitive and mobility capacity

\begin{tabular}{lcc}
\hline Psychomotor condition of the patient & $\mathbf{n}$ & $\%$ \\
\hline Cognitive and mobility impaired to request help to urinate & 14 & 46.7 \\
Cognitive preserved to request help to urinate & 14 & 46.7 \\
Preserved mobility to go to the toilet & 2 & 6.7 \\
Total & 30 & 100.0
\end{tabular}

Table 2 - Presence of nursing annotation and evolution of the nurse related to the use of the external catheter

\begin{tabular}{|c|c|c|}
\hline Frequency of related nursing annotation & $\mathbf{n}$ & $\%$ \\
\hline No & 17 & 56.7 \\
\hline Yes & 13 & 43.3 \\
\hline Total & 30 & 100.0 \\
\hline
\end{tabular}

Frequency of related nursing evolution

\begin{tabular}{cccc} 
& No & 30 & 100.0 \\
& Yes & 0 & 0.0 \\
Total & & 30 & 100.0 \\
\hline
\end{tabular}

Table 3 - Changes in the skin caused by the use of the external catheter

\begin{tabular}{lcc}
\hline Skin changes & $\mathbf{n}$ & $\%$ \\
\hline None & 20 & 66.7 \\
Friction injury & 7 & 23.3 \\
Dermatitis & 2 & 6.7 \\
Edema & 1 & 3.3 \\
Ulcer & 1 & 3.3 \\
Total & $31 *$ & 103.3 \\
\hline
\end{tabular}

Note: * The total number of skin changes is higher than the sample number because one patient had two changes.
Table 4 - Care provided by nursing professionals for patients using an external catheter

\begin{tabular}{lcc}
\hline Received guidance & $\mathbf{n}$ & $\%$ \\
\hline No & 21 & 70.0 \\
Yes & 9 & 30.0 \\
Total & 30 & 100.0 \\
\hline Hygiene of the penis & & \\
\hline Less than once a day & 1 & 3.3 \\
Daily & 29 & 96.7 \\
Total & 30 & 100.0 \\
\hline Exchange frequency & \multicolumn{2}{c}{} \\
\hline More than one exchange a day & 1 & 3.3 \\
Daily & 29 & 96.7 \\
Total & 30 & 100.0 \\
\hline
\end{tabular}

\section{DISCUSSION}

It is noteworthy that MECA has been indicated for patients with motor conditions for papagaio (Papagaio is a urinary vessel used to collect urine from people who are bedridden and/or have difficulty locomotion. This reservoir is suitable for people with physical disabilities, multiple disabilities and the elderly) or toilet use and/or cognitive conditions to request assistance at the time of urination. The device in question is indicated instead of diapers and absorbents, for incontinent patients due to different etiologies, to avoid urine contact with the skin, however, it is usually composed of latex, material of high allergenic potential, besides exposing the skin to risk of injury from the constant use of masking tape $\mathrm{e}^{(2-4)}$.

In addition to the fact that the device was indicated to patients who could benefit from other means of aiding the voiding act, the indication of use did not appear in the medical records, making it difficult to evaluate the professional and reason for the indication on the day of the installation. The lack of records was evident both in the lack of prescription of the nurse for the installation of the device and prescription for maintenance care of the MECA, as well as in the absence of mention of the use of the device and care provided in nursing notes and nurse evolution.

According to Resolution 429/2012 of the Federal Nursing Council, in Article 1, all care provided in nursing care must be recorded in medical records ${ }^{(9)}$ :

It is the responsibility and duty of Nursing professionals to record, in the patient's medical records and in other documents of the area, both in the medium of traditional support (paper) and in electronic media, the information inherent in the care process and the management of the necessary to ensure the continuity and quality of care.

The annotation of the nursing team, among them the assistants and technicians, is essential for the implementation of the Systematization of Nursing Care (SAE - Sistematização da Assistência de Enfermagem $)^{(10)}$, including the evolution as a private assignment and duty of the nurse ${ }^{(11)}$. According to COFEN Resolution 358/2009, which provides for the SAE through the nursing process, it is up to the nursing assistant or technician 
to implement the prescriptions of the nurse that is appropriate under his supervision and guidance ${ }^{(12)}$. Qualitative research carried out with nurses, assistants and nursing technicians in 2015 at a Hospital School of Minas Gerais State also revealed deficiencies in the work process due to the disqualification of nursing records ${ }^{(13)}$.

As already mentioned, the MECA is a strategy with clear indications that can be a benefit to the patient without control of the voiding act, however, it is not free of risks and the main one is the skin lesion. One-third of the patients had skin changes caused by improper placement or maintenance of the device.

The literature cites that leakage of urine can lead to local irritation, maceration, and ulcerative processes ${ }^{(1)}$. EAUN describes that MECA, when properly installed, should ensure leak-free drainage of urine to the collection flask, thus favoring skin comfort and integrity ${ }^{(5)}$. In a study conducted with men with spinal cord injury, aged between 20 and 70 years, hospitalized using MECA, 15\% presented irritating or compressive complications as a consequence of inadequate use of the device ${ }^{(14)}$.

Another intriguing result was related to the care with the MECA installation, this research revealed that a minority of patients were submitted to the previous removal of the hair, diverging with guidance from the EAUN that recommends trimming the hairs in situations that could get stuck in the device ${ }^{(1)}$.

In this study, all the patients had the catheter fixed with adhesive tape, mostly microporous, without previous allergy test. It is noted that there was no selection of the form of fixation of the MECA according to the evaluation of the individual conditions of the patient, which may be associated with the number of skin lesions already mentioned.

There are several ways to attach the MECA, among them are micropore paper adhesive tapes, special tapes such as double face, hydrocolloid strips, elastic with velcro and even devices that are self-adhesive. The literature points to the importance of choosing the appropriate adhesive for each case ${ }^{(15)}$. The use of adhesive tapes is the least safe strategy, both to avoid leakage and to expose the patient to the risk of skin, allergic or traumatic injury. The EAUN guidelines recommend the testing and use of self-adhesive or double-sided adhesive ${ }^{(1)}$.

It can be considered that the care provided to patients using MECA who composed the sample of this study had cascading limitations, it was not evidenced a detailed evaluation of the patient for the prescription of the device by the nurse, in this way the installation was performed in a standard way and not individualized by the assistant or nursing technician, using the available device, as well as the fixation tape. With the device already installed there was no prescription for maintenance care, once again the care was not individualized, the frequency of hygiene and exchange coincided with the international recommendations, however the orientation to the patient and the relatives was not observed in the vast majority of cases.

Regarding the need for patient and family counseling, the European guideline emphasizes the importance of clarification before the evaluation and indication of the use of the $\mathrm{MECA}^{(1)}$. In addition, the nursing team professionals are governed by a code of ethics that ensures, in Article 17 where the patient, family and community are informed about the risks and benefits of care provided ${ }^{(16)}$.

Regarding the MECA exchange, the predominance was daily change after intimate hygiene in line with international recommendations, however in cases of urine leakage or MECA detachment, the frequency should be adjusted ${ }^{(1)}$. It is worth mentioning that the number of exchanges greater than once a day was lower than the number of patients who showed leakage of urine, again denoting the process.

The Regional Nursing Council of São Paulo (COREN-SP - Conselho Regional de Enfermagem de São Paulo) recommends the creation of standard protocols and procedures that support SAE in the care of the insertion and management of the MECA by the nursing team $^{(17)}$. The fact that the service studied does not have a protocol or standard operating procedure, nor did it have the capacity of the team to provide such care, can, in a way, justify the data found.

According to Silva ${ }^{(18)}$, the deadlocks for the fulfillment of the SAE involve theoretical and practical ignorance of nursing, besides the absence of resource and time for its execution, denoting a professional practice without adequate scientific background.

The results found and the comparison with current literature should motivate a more careful look at the population of patients with indication of MECA use, in order to think about the development of care protocols, as well as the team's qualification for the procedure and its valorization as a nursing care that involves its risks and benefits.

\section{Study limitations}

As limitations of the study, the fact that the catheter's residence time was not considered as a variable and the small sample size reached during the study period.

\section{Contributions for the sector of Nursing}

As a suggestion for future study, it is observed the need for more robust epidemiological studies regarding the use and performance of the team in the use of the MECA, participatory research to create care protocols based on the limitations and potential presented by the nursing teams, as well as clinical studies to validate these protocols.

\section{CONCLUSION}

There was no individualized evaluation of the patient to indicate the use of MECA, evidenced by the number of patients using the device without indication, because they presented motor and cognitive conditions for controlled urination without its use.

Nursing records did not include prescription of installation, prescription of care or assistance rendered with a focus on the use of MECA. The use of a latex device and micropore paper adhesive tape was predominant, demonstrating once again a standard and non-individualized care, with exposure of the patient to the risk of skin lesion through the contact of allergenic and traumatic products. The skin lesion was present in the sample.

The exchange of the device and intimate hygiene coincided with international recommendations, with a few exceptions that hygiene should have been done more than once a day when the device needed to be replaced. Patients and their families were not advised about the use of MECA.

The absence of protocols, Standard Operational Procedures or training of the teams for indication, installation and maintenance of the device in question can justify the results found. 


\section{REFERENCES}

1. Geng V, Cobussen-Boekhorst H, Lurvink H, Pearce I, Vahr S. Evidence-based guidelines for best practice in urological health care: male external catheters in adults urinary catheter management. Arnhem: European Association of Urology Nurses; 2016.

2. Averch TD, Stoffel J, Goldman HB, Griebling TL, Lerner L, Newman DK, et al. AUA white paper on catheter associated urinary tract infections: definitions and significance in the urological patient. J Urol Pract. 2015;2:321-8. doi: https://doi.org/10.1016/j.urpr.2015.01.005

3. Blok B, Pannek J, Castro Diaz D, Popolo G, Groen J, Gross T, et al. EAU Guidelines on neuro-urology. Eur Urol[Internet]. 2009 [cited 2018 Mar 18];56(1):81-8. Available from: https://uroweb.org/guideline/neuro-urology/\#6

4. Brodie A. A guide to the management of one-piece urinary sheaths. Nurs Times [Internet]. 2006[cited 2018 Mar 18];102:49. Available from: https://www.ncbi.nlm.nih.gov/pubmed/16539324

5. Cottenden A, Bliss DZ, Buckley B, Fader M, Gartley C, Hayder D, et al. Management using continence products. Arnhem, The Netherlands: International Consultation on Urological Diseases-European Association of Urology; 2013. p. 1651-786.

6. Gammack JK. Use and management of chronic urinary catheters in long-term care: much controversy, little consensus. J Am Med Dir Assoc [Internet]. 2002[cited 2018 Mar 18];3:162-8. Available from: https://linkinghub.elsevier.com/retrieve/pii/S1525-8610(04)70309-6

7. Vaidyanathan S, Selmi F, Abraham KA, Hugles P, Singh G, Soni B. Hydronephrosis and renal failure following inadequate management of neuropathic bladder in a patient with spinal cord injury: case report of a preventable complication. Patient Saf Surg [Internet]. 2012[cited 2018 Mar 18];6:22. Available from: https://www.ncbi.nlm.nih.gov/pmc/articles/PMC3495664/

8. Diniz RV, Albuquerque CC, Matos SDO, Lima AC, Soares MJGO. Revisão integrativa da utilização de cateteres externos em pacientes com incontinência urinária. Estima [Internet]. 2014[cited 2018 Mar 18];12(4). Available from: https://www.revistaestima.com.br/index.php/ estima/article/view/341

9. Conselho Federal de Enfermagem. Resolução n 429/2012, de 30 de maio de 2012. Dispõe sobre o registro das ações profissionais no prontuário do paciente, e em outros documentos próprios da enfermagem, independente do meio de suporte - tradicional ou eletrônico [Internet]. Diário Oficial da União. 2012 [cited 2018 Mar 18]. Available from: http://www.cofen.gov.br/wp-content/uploads/2012/03/ Res_429_2012_pag2.pdf

10. Conselho Federal de Enfermagem. Resolução n 0514/2016, de 05 de maio de 2016. Aprova o guia de recomendações para os registros de enfermagem no prontuário do paciente, com a finalidade de nortear os profissionais de Enfermagem [Internet]. 2016 [cited 2018 Mar 18]. Available from: http://www.cofen.gov.br/resolucao-cofen-no-05142016_41295.html

11. Conselho Federal de Enfermagem. Resolução n 311/2007, de 8 de janeiro de 2007. Aprova a Reformulação do Código de Ética dos Profissionais de Enfermagem [Internet]. 2007 [cited 2018 Mar 18]. Available from: http://www.cofen.gov.br/resoluo-cofen-3112007_4345.html

12. Conselho Federal de Enfermagem. Resolução n 358/2009, de 15 de outubro de 2009. Dispõe sobre a Sistematização da Assistência de Enfermagem e a implementação do Processo de Enfermagem em ambientes, públicos ou privados, em que ocorre o cuidado profissional de Enfermagem, e dá outras providências [Internet]. 2009[cited 2018 Mar 18]. Available from: http://www.cofen.gov.br/resoluocofen-3582009_4384.html

13. Borges FFD, Azevedo CT, Amorim TV, Figueiredo MAG, Ribeiro RGM. Importância das anotações de enfermagem segundo a equipe de enfermagem: implicações profissionais e institucionais. Rev Enferm Centro-Oeste Min [Internet]. 2017 [cited 2018 Mar 18];7:e1147. Available from: http://dx.doi.org/10.19175/recom.v7i0.1147

14. Golji H. Complications of external condom drainage. Paraplegia. 1981;19:189-97.

15. Cameron AP, Jimbo M, Heidelbaugh JJ. Diagnosis and office-based treatment of urinary incontinence in adults. Part two: treatment. Ther Adv Urol [Internet]. 2013[cited 2018 Mar 18];5(4):189-200. doi: http://dx.doi.org/10.1177/1756287213495100.

16. Conselho Regional de Enfermagem do Estado de São Paulo. Principais legislações para o exercício da enfermagem: $2015-2017$ [Internet]. 2017[cited 2018 Mar 18]. Available from: http://portal.coren-sp.gov.br/sites/default/files/principais_legislacoes_web.pdf

17. Conselho Regional de Enfermagem do Estado de São Paulo. Câmara Técnica. Orientação Fundamentada n.093/2017. Assunto: URIPEN ${ }^{\circledR}$ em ILPI. [Internet]. 2017[cited 2018 Mar 18]. Available from: http://portal.coren-sp.gov.br/sites/default/files/Orienta\%C3\%A7\%C3\%A3o\%20 Fundamentada\%20-\%20093_2.pdf

18. Silva MCN. Sistematização da assistência de enfermagem: desafio para a prática profissional. Enferm Foco [Internet]. 2017[cited 2018 Mar 18];8(3):7. Available from: http://revista.cofen.gov.br/index.php/enfermagem/article/view/1534 